ISSN: $2450-6869$

eISSN: 2719-6763

No. 10,2020

\section{DEFENCE SCIENCE REVIEW}

http://www.journalssystem.com/pno/

DOI: $10.37055 / \mathrm{pno} / 133847$

\title{
Declared security versus security reality
}

Original article

Accepted: 20 November 2020

Published: 14 December 2020

Peer review:

Double blind

Keywords:

declared security, perceptual capabilities, social symptoms

This work is licensed under the Creative Commons AttributionNonCommercial-NoDerivatives 4.0 License

\author{
Edward Karczewski ${ }^{1}$ \\ ORCID (iD) 0000-0003-3614-3778
}

Military University of Technology in Warsaw, gen. Sylwestra Kaliskiego 2, 01-476 Warszawa

\begin{abstract}
The article highlights the main factors that determine the risk to security, as well as the adequacy of its assessment among the respondents, including the identification of situations when external or internal threat is serious while its perception is at the minimum level.
\end{abstract}

\footnotetext{
${ }^{1}$ Edward Karczewski, Ph.D. - Assistant Professor at the Institute of Security Systems and Defence of the Faculty of Logistics at the Military University of Technology in Warsaw Research interests: psychology, cultural anthropology, defence.E-mail: edward.karczewski@wat.edu.pl.
} 


\section{Introduction}

The article is an attempt at exaggeration of what is often not obvious, but what should be clearly pointed out in terms of the declared and actual state of security, as the reality is often different from what is believed and claimed. Thinking in scientific terms requires images, while interpretation requires concepts. In the words of Immanuel Kant, "Thoughts without content are empty, intuitions without concepts are blind". According to many authors, this dualism is the basis for the distinction between scientific and research reality and possibility. The perceptual capabilities of homo cognitans - with the exception of medical cases - tend to be unrestricted, while his cognitive realities are determined by a whole set of intermediary variables which prevent cognitive realism. Such variables include, for example, defective functioning of the state, law, institutions, excessive bureaucratism, media manipulation, impoverished interpersonal communication, excessive consumption, indifference, COVID-19 or the so-called ho-hum attitude. The cumulation of all these factors leads to a veritable "Tower of Babel", including, above all: lack of agreement, sensory deprivation, irrational aggression, fear, conspiracy hypotheses, etc.

It often turns out that under conditions that limit or disrupt the perception processes, subtle differences between the reality and cognitive possibilities are eliminated. This affects both the paradigm of abstract thinking, as well as analysing issues or phenomena related to one's security.

\section{The essence of security}

In the literature on the subject, one can find over 150 clear and specific definitions of security. But the point lies not in the very description of the phenomenon, which is often too categorical. As it turns out, the sudden multitude of various social processes, taking place "here and now", leads to the modification of the definition and a slightly more careful approach to the sense of security. Generalisation of reality, on the other hand, can lead to schizoid insanity. Excessive distrust and more so disregard for certain social symptoms may turn out to be signs of infantilism. Most people know "the way it is", but not so many wonder "why it is the way it is", while "the way it will be" - what will happen in the future - is addressed by no one, except for fortune tellers. Unless one were to consider astrology or palmistry a scientific method of learning about reality. Therefore - as it seems - the understanding of security should be considered from the basic designation, namely preserving and maintaining the broadly defined phenomenon of life. As is rightly pointed out by R. Nacht - there is one sacred thing in the universe - life. And in every form of existence, whether it is grass, ants or human beings, there is one and the same life. And one should cherish it above all else. There is no doubt that people are waking up. They are ready to live in the new world. Thus, an aspect of a more general understanding of the problem, i.e. the dependence of descriptive thinking on symbolic thinking, becomes apparent. It enhances the ability to reflect, as people are aware of their own awareness. "Without symbolism, human life would resemble the life of the prisoners in Plato's famous parable. Man's life would be confined to his biological needs and practical interests; it would not have access to the world offered by religion, art, philosophy and science" (Cassirrer, 1997, p. 106). 
Security is most often interpreted as the continuous achievement and maintenance of the state of the lack of threats and freedom of human action; it is a process of continuity that offers possibilities of biopsychic and social human development. According to the widespread, but well-proven theory of needs put forward by A. Maslow- the sense of security is one of the most important requirements in the life of each of us. Other motives seem to lose their meaning when objectively/subjectively functional factors increase a threat to life, uncertainty or fear. Fear is a feeling inherent in all higher life forms. It often leads to harmful and even destructive consequences. It can generate such negative feelings as aggression, hatred or anger. Fear always has an objective context, we are afraid of something that is a threat to us, which is a source of negative emotions. According to some experts - under the influence of these kind of feelings, man is also able to survive and act in a way so as avoiding events that could potentially pose a certain threat. He also uses it intuitively to explore and assess actual situations. This is probably due to the fact that cause and effect are the beginning and end of everything. They teach us about general patterns and principles of how the world, man and interpersonal relations work, which is worth remembering (Klichowski, 1994, p. 10):

- every action, thought or intention is a record in a peculiar "interpersonal file", it is like a boomerang which comes back to us in the appropriate time;

- the things or phenomena which are observed at present, and which disturb normal human functioning, are a derivative of the actions taken in the past; as the saying goes: you reap what you sow.

- people are able to make rational decisions. And it is up to us how we think, what we say and how we act.

Man is able to take into account the future consequences and results of his own actions. He is aware that good causes generate positive effects - it is not enough to know - you need to understand as well. But it is very difficult to pass on one's understanding to someone else. In the opinion of G. I. Gurdjieff, this inability to internalise understanding causes deep social and political divisions. It intensifies interpersonal antagonisms, prevents open and frank interpersonal communication; it inhibits the development of individuals and social communities. There is a belief that... unlike animals, man is not guided by instincts and urges. Compared to people in the old days, he is not guided by traditions and values. Not knowing what he is allowed or not allowed to do, what he should or should not do, he often does not even know what he wants. As a result, he does what other people do, which is called conformism (Kulczyk, 2004, p. 70). However, the main source of a sense of security, happiness or threat is personal life. It can be improved and perfected through appropriate education, creative activity and development of awareness.

What is meant by maintaining security is a guarantee of peace, continuity, trust and a sense of identity of an individual. In general, security is described in terms of threats; the use of force or coercion. However, subjective, objective and functional dimensions of security are evolving. Depending on the sense of security, the world can be perceived in various ways, e.g. (Karczewski, 2016, p. 119):

- as a collection of interconnected parts;

- as a measurable phenomenon; 
- as a phenomenon that can be controlled;

- a phenomenon that is responsive but remote;

- as a unique phenomenon that happens to people, but is not measurable;

- a source of choices;

- as an addressable phenomenon.

Thus, we usually perceive activities and things around us as processes, conditioned by other phenomena and processes, which we use to perceive the measurable, separate world. This world exists as an object, according to individual preferences. By perceiving it, one can "communicate" with others, although its perception is different for everyone. The reality seen in this way is highly unreliable. It is impenetrable. There is no consistency in it, as everything permeates everything else. In this context, the perception of a sense of security may reflect the real state of affairs (potential/real threat) or may be false - a misperception. A good example is the exaggerated fear of infection with COVID-19. However, a significant percentage of the population (approx. 26\%) does not respect warnings related to the pandemic threats - is such a high number of respondents right? Misperception is the result of high complexity of securityrelated conditions, simultaneous reception of true and false information, as well as cognitive impairments of the perceiver (see the photograph below). These factors, but also the variability of the components of security, make it difficult to identify them or construct a general theory of undisturbed human existence and development.

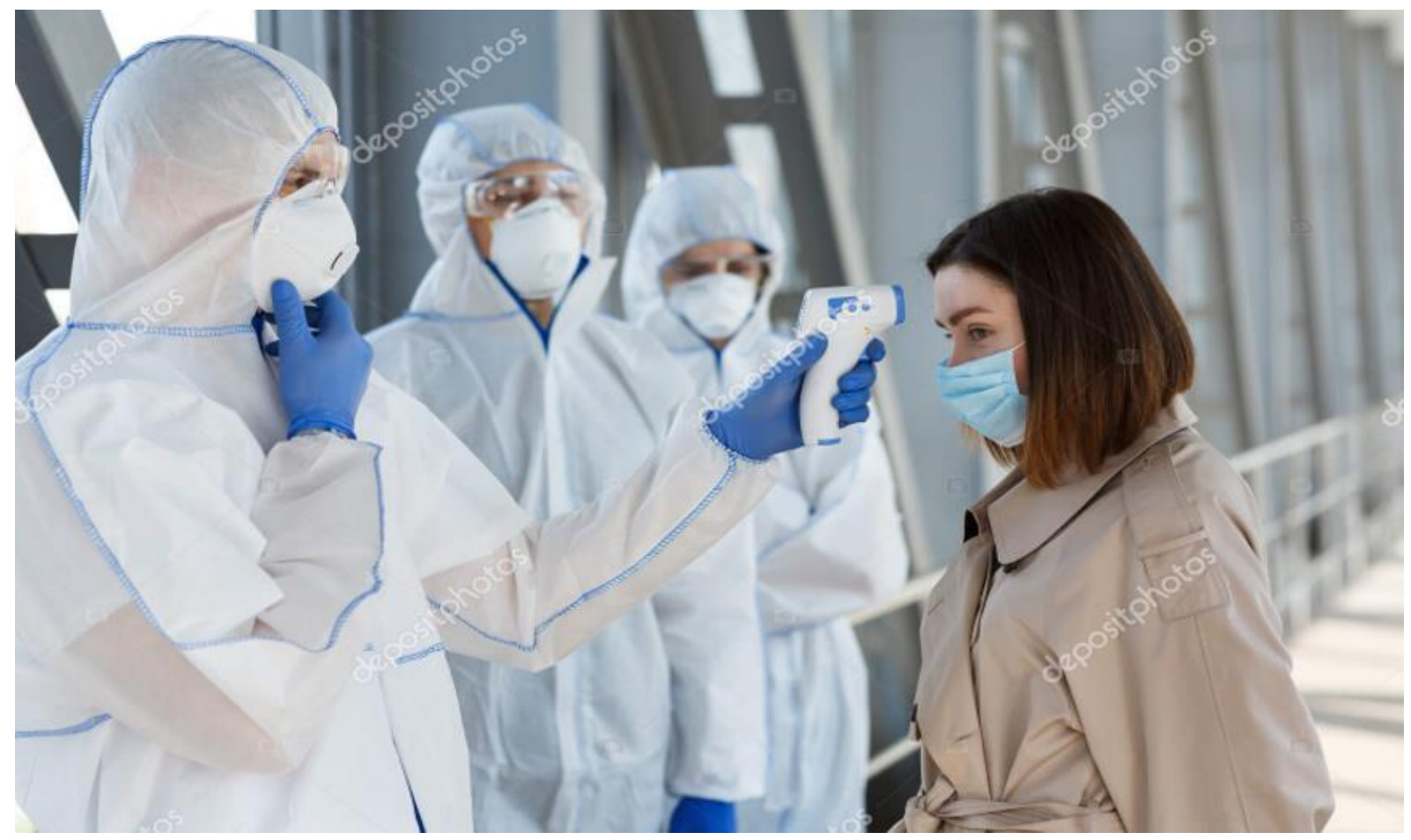

Fig. 1. Medical workers in protective suits

Sourece: https://pl.depositphotos.com/358520016/stock-photo-medical-workes-in-protectivesuits.htlm

It is worth to note that in order to be convincing and useful, the concepts must include both objective and subjective measures of the sense of security, including (Zięba, 2012): 
- the presence of a real, long-lasting external threat and the perception of that threat that is not imaginary;

- a state of obsession that intensifies when a minor threat is treated as a serious one;

- a misconceived sense of the lack of threat to security, i.e. perceiving a situation where the external threat is serious as insignificant threat;

- a sense of security felt when the threat is almost imperceptible and its perception is very accurate.

For this reason, it is not enough to look - one has to see, it is not enough to see - one has to perceive, it is not enough to perceive - one has to act. By disregarding or underestimating the importance of a sense of security can paradoxically lower it. This is often due to the fact that people differ considerably in their assessment of social risks. The factors that have an impact on the above-mentioned process include, in particular (Stanisławiak, 2004, p. 58):

1) type of temperament and mood (positive mood is conducive to a favourable assessment of a thing or a phenomenon, while negative mood paves the way for negative judgments);

2) "cognitive closure" (it intensifies in critical and stressful situations, due to the lack of time or information, or the so-called priority effect - authentication of earlier information);

3) cognitive overload (in such a condition, one does not take into account situational pressure and fails to use the incoming information);

4) cultural differences (a different value system may cause the same behaviours to be interpreted differently; more open and less dogmatic people are able to use knowledge better and take into account cultural patterns);

5) self-esteem (individuals with high self-esteem experience negative emotions less frequently and are able to resist them and to think in positive terms about themselves and others);

6) cognitive complexity (formal features of cognitive structures - this complexity increases the awareness of one's own distinctness in thinking and acting in order to ensure the security of the social community).

In a situation of a particular intensification of security threats, i.e. in times

of the peak of the crisis, the actions taken may change the existing principles of operation of public authorities and limit human freedom and rights in a completely different way than in the case of other, less serious threats. Considering the importance of the protection of the highest values, they have the power to significantly alter civil rights or even suspend them.

\section{Declared opinions on the state security}

Research conducted by CBOS in 2019 on a representative sample of Poles illustrates their declared sense of security in the country. The data obtained using the diagnostic survey method indicates that:

1. $89 \%$ of the respondents answered that Poland is a safe country to live in; the percentage share of negative responses was $8 \%$, while $3 \%$ of the respondents had no opinion. Positive opinions about state security tend to increase along with greater education/awareness and material status (higher earnings per person in the household). 
2. Approximately $98 \%$ of the respondents believe that their immediate vicinity (district, housing estate, village) can be considered as safe. This percentage is even greater than the percentage of respondents with high sense of security in the country. The lowest percentage of positive opinions was found in the group of pensioners (94\%) and the unemployed $(91 \%)$. In turn, in some groups the sense of security fluctuates between $99 \%$ and $100 \%$. It applies mostly to the self-employed people, people in management positions and professionals with higher education.

3. The survey results show that the growing general sense of security stems from an increase in the number of people who are not afraid to fall victim of a crime. According to the data, $66 \%$ of the respondents do not perceive such a threat, and $33 \%$ are concerned about their safety. Men are less often concerned about their safety than women ( $75 \%$ and $58 \%$ of the respondents, respectively, answered negatively). Slightly more than half of the respondents $(52 \%)$ are sure about the safety of their families. But approx. $46 \%$ of the respondents worry that someone from their closest family may fall victim to a crime.

4. The sense of threat related to having someone close becoming a victim of a crime increases with the population size of one's place of residence. A significant difference in this respect can be observed between agglomerations of up to 100,000 people and above 100,000 .

5. Unskilled workers and self-employed people tend to be more worried about the safety of their relatives than other groups (56\% and 58\% respectively, answered that they fear that someone from their immediate family may fall victim to a crime); this is particularly true of people at the age range of 35-44 (56\%) and those who live in the largest cities (62\%). However, compared to 2018, the results are within the statistical error, as $52 \%$ of respondents are sure about the safety of their relatives.

6. The percentage of respondents who do not feel the threat of crime reached $51 \%$ for the first time. This indicates an upward trend compared to the results from 2018 (by 5\%). On the other hand, $42 \%$ of the respondents express moderate anxiety ("I am afraid, although not so much"). Almost $7 \%$ of respondents experience a serious anxiety for themselves or their relatives ("I am very afraid"), which is 3\% lower than in 2018.

The increase in the sense of security is also reflected in the individual experiences of the respondents. These experiences have an impact on one's beliefs; they often heighten and sharpen attention, and change people forever.

\section{The security reality is not what it seems}

Each perception of reality is accompanied by delusions. Whether we like it or not, this is a fact. It is worth to have it in mind, because otherwise our perception of what is happening around us will be imaginary. But the perception trap is both deceptive and dangerous. See the figure below: 


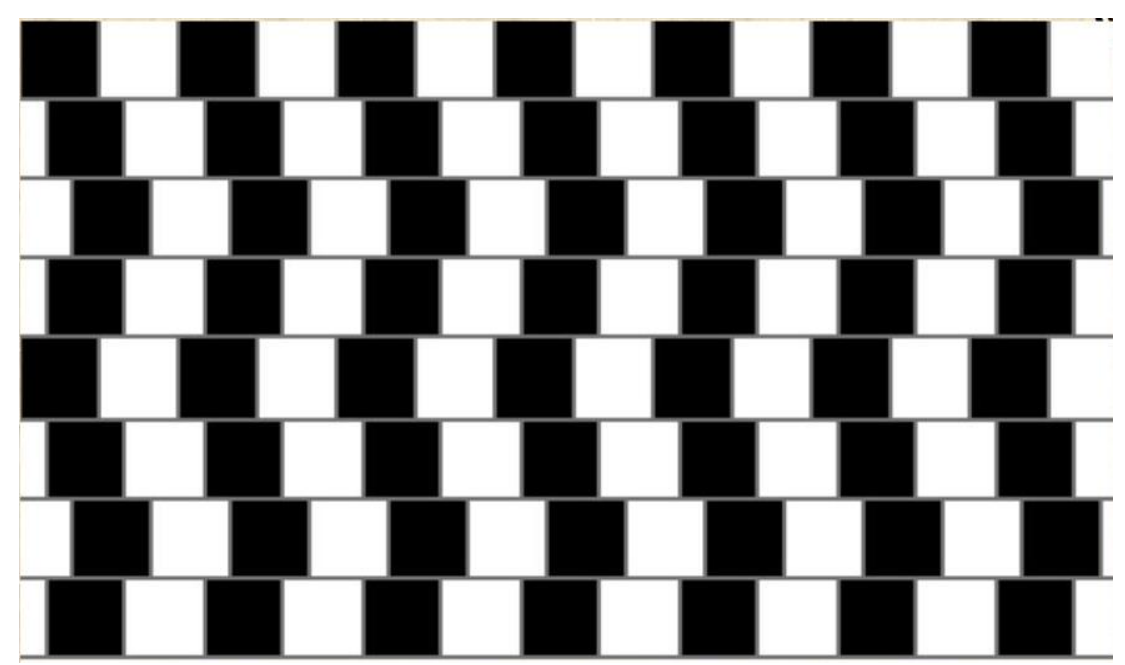

Fig. 2. Perceptual illusion - are the horizontal lines straight?

Source: own elaboration

Man cannot experience himself only with the use of some psychophysical ability. This feature is mainly a reflection of the intellectual and emotional reaction to one's own situation in a given environment. Someone may interpret their thoughts and beliefs about themselves or other people, which is not to mean that they understand everything in this regard. The human mind - as many authors observe - wants to discover this secret, but - as it turns out - cannot do it only with its own power. Spiritually mature people experience themselves authentically, establish positive social relationships and values, care for the natural environment, and do not shrink away from changes in the paradigms of thinking and acting. Spirituality, therefore, becomes the main regulator of their behaviour. Scientific research verifying the accuracy of these observations proves that when individuals or larger communities become spiritually sterile, they are more often inclined to self-destruction. To give an example, there is a hypothesis that the Mayan civilisation began to decline as early as the ninth century, when ordinary people began to lose faith that their kings were gods. Sumptuous buildings were no longer built, large cities were deserted. In addition, excessive and ill-considered interference with the natural environment inevitably led to a catastrophe.

The key aspect of the spiritual sphere is that people can look into themselves in an attempt to answer the question of who they are and who they want to be. This does not only apply to obtaining information in terms of emotional or physical well-being, but also about oneself as an immaterial whole. According to J. Krishnamurti (Krishnamurti, 2008, p. 38), the cause of all the chaos in the world lies in isolation and individuality. Chaos and fear are therefore the result of the exploration of the "human brain" in all areas of life. Man needs material security, but is there security in the psychological image of transcending of who he truly is? According to E. Tolle (Tolle, 2003, p. 29), there is a dimension of awareness deeper than thought, within which the authentic meaning, of life is revealed. This is the essence of what man is. If man is not conscious of himself, he lives far below his capabilities. Therefore, the purpose of education is to make people realise that there are higher states of perceiving the reality and 
that it is possible to achieve them with the help of appropriate knowledge and mental training. You are not able to comprehend even the shadow of what man is capable of achieving. But nothing can be achieved while "dreaming". In the consciousness of a "sleeping" man, his delusions, his dreams are mixed up with reality. He lives in a subjective world that he can never escape from. For this reason, he can never make use of all the powers he has, and that is why he only lives a small part of himself (Kulczyk, 2004, p. 183).

The quality of human experience with regard to various threats teaches us that we can change our perceptions of reality. We can not only perceive the forms of things, but also understand their causes. The depth of self-awareness enables a richer and more faithful perception of reality, as well as a more detailed insight into what is happening around us. It is not limited to one monopolistic view of the state of affairs or being right at any cost. It can take into account different points of view and reasons of others. Therefore, the dialogue between power and science is authentic, based on the reality and actual needs, and not only on the - often conflicting - opinions of the "authorities". For this reason, it is often viewed as pathology of "dogmatic authoritarianism", far from trust in the dictator, but subject to his will.

The contemporary reality poses an increasing threat to the sustainable development of people and their social functioning. There is no doubt that the threat to ontogenetic/individual security leads to diminishing collective security. There are several reasons at play, including:

- excessive pursuit of wealth and power;

- permanent rush, workaholism, no time to relax;

- superficial, impoverished interpersonal communication (strong barriers in the process of dialogue);

- pushy advertising on TV and lack of criticism in the reception of propaganda information

- conspiracy thinking destroying the awareness of social communities;

- antagonising age, professional and other groups of people;

- failing or dysfunctional health systems;

- disruptions in perception, thinking and assessment of what is happening "here and now";

- strange interpretations of the world and its functioning;

- multifaceted and persistent social crises;

- an irresistible desire to destroy other living beings;

- succumbing to any kind of moral corruption;

- alternating between strong dependence on the "authorities" and disappointment or even contempt towards them;

- $\quad$ and numerous other factors leading to unpredictable crises.

It can be said that individual security also includes unidentified external threats of a general, environmental, health, economic and social nature. For example, prof. R. Flisiak (Head of the Polish Society of Epidemiologists and Physicians of Infectious Diseases) - when speaking about the current threat to health security, emphasises that "people must have prospects of a normal life". In his view, this will enable the society to withstand a lot more, and if such a possibility is taken away, a rebellion is likely to occur. A complete lockdown would be 
unhealthy for everyone; shutting down the economy could lead to a situation that we had no money to treat people, but psychological aspects must also be taken into account. - But what kind of psychological aspects? The author does not elaborate on it.

However, it can easily be guessed - this is about the phenomenon of sensory deprivation. And lockdown is its best example. Suffice to say that sensory deprivation can even drive one insane. The state of being isolated and cut off from external stimuli generates mental disorders. This is due to the fact that the human brain does not like to be switched off for a long period of time. Therefore, it generates hallucinations and disrupts most mental processes. As regards the "quackery" medical experiment involving face masks, it is better not to ask what others have to say about it.

Research and observations prove that the threats to the continuity and development of an individual are coupled with economic aspects (e.g. decline in production, shortage of material goods). They give rise to aggression and interpersonal misunderstandings that can lead to the use of force and involve ever larger social groups. There are also security threats posed by public movements or culturally different groups that are manifested in the form of claims or aggressive protests against state institutions or authorities. All this is accompanied and aggravated by fear on both sides of the conflict. What even the most primitive living beings must feel, managing fear is the last procedure of their annihilation.

Managing fear is the last procedure of their annihilation. In humans, however, fear paralyses rational thinking and acting, leaving only the so-called escape mechanism to regain freedom and return to the state of the lack of threats. Managing fear is becoming increasingly "fashionable". It is a social engineering and propaganda strategy involving the instrumental use of fear in order to control and manipulate an individual, group, and larger social community. It consists in the conscious, intentional and effective generation of fears or panic, as a result of which people, overwhelmed with such asthenic emotions, lose their selfawareness. They no longer know who they really are. This is an example of a total oligophrenic disruption between the balance of the "heart" and the mind. A significant symptom of fear management is confusion in terms of the sense of security and the actual threat to it.

\section{Conclusions}

The declared security and the security reality, whether we like it or not, are not identical or harmonised. Verbal declarations obtained in the results of the diagnostic survey do not have to be entirely true. In the modern culture, misfortune and threat is often equated with the determinism of events that will inevitably occur. There is a rejection of a reflection and assessment of the factual state of affairs in favour of an attitude that assumes a random course of events. But the future is shaped by people in accordance with their ability to assess risk. Blind luck does not rule it out.

Without an adequate risk assessment, it is difficult to perceive the security reality, even less so to make an attempt to interpret it. For example, the COVID-19 pandemic, both in Europe and other continents, has brought an unprecedented period of uncertainty. The transmission of the 
disease is a particularly elusive threat, since it is imperceptible, undefined, and insidious. And it is impossible to say with certainty what will happen in a month or a year.

It is worth to note that as early as five centuries ago, the author of "The Prince" - N. Machiavelli (treated by some as an unscrupulous person, and by others as the one who perceives the world without a mask or embellishment) wrote that: (...) Fortune may be the arbiter of one half of our actions, but she still leaves us the other half, or perhaps a little less, to our free will. (...) A prince may be seen to be happy today and ruined tomorrow without having shown any change of attitude or character. (...) I also believe that he will be successful if he directs his actions according to the spirit of the times, and that if his actions do not accord with the times, he will not be successful (Machiavelli, 1984). It may, therefore, be justified to say that what is to come is determined by the openness of man to improve his individual life and ensure the possibility of his undisturbed development. But it may well turn out that the so-called objectivised calculation of the results does not guarantee their absolute certainty. - It is difficult to rule out human error or other factors at play. 


\section{References}

Beck, U. (2002). Spoteczeństwo ryzyka. W drodze do innej nowoczesności. Warszawa.

Brogard, B. (2014). Does perception have content? Oxford: Oxford University Press.

Dworecki, S. (1994). Zagrożenia bezpieczeństwa państwa. Warszawa: Akademia Obrony Narodowej.

Dębowski, J., Jarmoch, E., \& Swiderski, A. (2007). Bezpieczeństwo czlowieka a proces wsparcia społecznego. Siedlce: Wydawnictwo Akademii Podlaskiej.

Foucoult, M. (2010). Bezpieczeństwo, terytorium, populacja. Warszawa: PWN.

Frankl, V. E. (1975). The unconscious God. London: Hodder and Stoughton.

Gryz, J. (2010). Zarys podstaw bezpieczeństwa. Warszawa: Akademia Obrony Narodowej.

Jakubczak, R., \& Flis, J. (2006). Bezpieczeństwo narodowe Polski w XXI wieku. Warszawa: Bellona.

Jarmoszko, S., Kalita, C., \& Maciejewski, J. (2016). Nauki społeczne wobec problemu bezpieczeństwa. Siedlce.

Karczewski, E. (2016a). Bezpieczeństwo ontologiczne jako warunek równowagi czynnościowej, tożsamości i rozwoju człowieka. In Z. Trejnis (Ed.), Obronność Państwa. Uwarunkowania oraz organizacja bezpieczeństwa i obronności. Toruń.

Karczewski, E. (2016b). Transgresja negatywna a bezpieczeństwo ontologiczne człowieka. Defence Science Review, $1 / 2$.

Klichowski, L. (1994). Lęk - strach - panika. Przyczyny i zapobieganie. Poznań.

Konieczny, J. (2005). Bezpieczeństwo biologiczne, chemiczne jądrowe i ochrona radiologiczna. Poznań-Warszawa.

Korzeniowski, L. F. (2017). Podstawy nauk o bezpieczeństwie. Zarządzanie bezpieczeństwem. Warszawa: Wydawnictwo Difin.

Krishnamyrti, J. (2008). Calkowity inny sposób życia. Katowice.

Krysowaty, A., \& Świniarski, J. (2020). Bezpieczeństwo w „społeczeństwie nadzoru”. Warszawa: ELIPSA.

Kulczyk, \& K., W. (2004). Wprowadzenie do nauk Gurdżijewa. Łódź: Wydawnictwo „Ravi”.

Stanisławiak, E. (2004). Wybrane problemy psychologii społecznej. Warszawa: Wydawnictwo WSP (TWP).

Stenberg, J. R. (2011). Cognitive Psychology. Boston, Mass.: Cengage Learning.

Tolle, E. (2003). Mowa ciszy: Łódź.

Truczyński, P. (2011). Bezpieczeństwo europejskie: systemy, sytuacje, funkcjonowania. Wrocław Wydawnictwo Atla.

Wolniewicz, S. (2019). Ontologia sytuacji. Podstawy i zastosowania. Warszawa: PWN.

Wołejszo, J., \& Jakubczak, R. (2013). Obronność. Teoria i praktyka. Warszawa: Bellona. 